\title{
Efficiency Determinants in Brazilian Football Clubs
}

\author{
Marcelo Machado de Freitas ${ }^{\dagger}$ \\ UFSC \\ Rafael Araújo Sousa Farias ${ }^{\Omega}$ \\ Universidade de Brasília \\ Leonardo Flach ${ }^{*}$ \\ UFSC
}

\begin{abstract}
The aim of this study is to analyze the efficiency of Brazilian football clubs in generating revenues and the reasons behind it. To achieve this goal, we applied quantitative methods including Data Envelopment Analysis and Tobit regression modeling to data on the best clubs from 2012 to 2014, according to the Brazilian Football Confederation ranking. The results allowed for the inference that the largest Brazilian clubs, such as Grêmio (RS), Palmeiras (SP) and Vasco (RJ), were not efficient in any period under analysis. Others, such as Guarani (SP) and Guaratinguetá (SP), were efficient in all of years under consideration. With the Tobit regression model, we were able to determine that winning titles and the elite status of a given club are decisive factors in achieving efficiency. Included among the strategies that allow for greater efficiency in Brazilian clubs are the better utilization of stadiums and club assets, maximization of the financial worth of player popularity, and joining these with titles and a place in the A Series. Finally, the results of this study contribute to the strategic development of the football business, highlighting the positive effects that efficiency yields for clubs, thus supporting the growing body of research on sports management in Brazilian academia.
\end{abstract}

Keywords: Expenditure; Revenues; Football financial efficiency; Data Envelopment Analysis Tobit regression model.

Received in 04/17/2016; revised in 06/08/2016; accepted in 07/01/2016; divulgued in 01/23/2017.

\footnotetext{
*Author for correspondence:

${ }^{\dagger}$. Mestre em Contabilidade Institution: UFSC

Address: Rua Capitão Romualdo de Barros,

576, Carvoeira, Florianópolis, SC, Brazil CEP: 88040-600

E-mail: mmf.marcelofreitas@gmail.com
}

$\Omega$. Doutorando em Administração Institution: Universidade de Brasília

Address: Campus Universitário Darcy Ribeiro, Prédio da FACE, Brazil CEP: 70910-900

E-mail: farias-rafael@hotmail.com

\author{
$¥$. Doutor \\ Institution: UFSC \\ Address: Rua Itapeva, 153, Parque \\ São Jorge, Itacorubi, Florianópolis, \\ Brazil, CEP 88034-520 \\ E-mail: leonardo.flach@ufsc.br
}

Note from the Editor: The article was accepted by Bruno Felix. 


\section{INTRODUCTION}

$\mathrm{F}$ ootball is Brazilians' favorite sport and the most popular in the national media, being able to cause the most diverse feelings in the audience. It is a mix of passion, devotion and fanaticism (SILVA et al., 2014). Such feelings are expressed in different ways, from the simple ostentation of the team colors in garments to the extreme of having the club's symbol tattooed on their own skin (OLIVER, 1999).

In recent years, Brazilian football has experienced numerous changes. They were mainly caused by changes in legislation (REZENDE; CUSTÓDIO, 2012), an increased number of people interested in the club's management and financial conditions (investors, sponsors, members, fans, and media, among others) and the society's demand for more transparency in management. In 2004, Law no. 10.672 made mandatory the publication of the club's balance sheets and other financial statements in major newspapers, while, in 2011, Law no. 12.385 required that the same be disclosed on the club's websites (FREY; CUNHA, 2014). Football, which was a sport practiced and managed by amateurs, underwent the need to professionalize its management team (LEONCINI; SILVA, 2005).

Part of such revitalization process is followed and claimed by the media (REZENDE; DALMÁCIO, 2015) and new laws advance to this end. Recently, Law no. 13.155, of 4 August 2015, which was approved by the National Congress and signed by the President, created the Program of Modernization of Brazilian Football Management and Fiscal Responsibility (PROFUT). In addition, scientific studies have addressed the economic and financial aspects of the national football clubs, but most of these works (68.75\%) still focus on specific assets accounting and disclosure (LEITE; PINHEIRO, 2014; FLACH; MÜLLER, 2014).

An effective management and efficient use of financial resources are aspects that contribute to the clubs professionalization (HAAS, 2003b). In this regard, there has been a growing number of scientific studies following this line of thinking. Dantas and Boente (2012), for example, analyzed the efficiency of 14 national clubs, and concluded that Internacional (RS) was the most efficient club in both financial and sporting aspects. The work conducted by Dantas, Machado and Macedo (2015), besides highlighting the efficiency of 36 Brazilian football clubs, also examined which factors affected their performances.

Factors such as the business volume generated by football (RIBEIRO; LIMA, 2012), increased media coverage, investments made in the sector and the importance placed on the sport in Brazil (ANDRADE; RAMOS, 2015) allow us to state that this topic deserves more involvement from academics, especially in the field of corporate strategies (ZUNINO, 2006). Along with this, the fact remains that many clubs are currently in the process of formalizing their management, with traces of more amateur attitudes still remaining among directors (CUNHA et al., 2015). 
In view of the above, there is a need to assess the managerial performance of national football clubs and produce a knowledge that contributes to discussions on the topic. Thus, the present study aims to assess the ability or efficiency of Brazilian clubs of generating revenues and the determinants of such efficiency.

We examined the major Brazilian football clubs in the 2014 league, according to the ranking published by the Brazilian Football Confederation (CBF) in 2015, using the Data Envelopment Analysis (DEA) and Tobit regression model. Although the DEA technique has been used in academic studies worldwide and in diverse fields of knowledge, its use in sports, especially football, is modest and recent (LAMPE; HILGERS, 2015).

The contribution of the present research is to provide elements to allow a better understanding of football-related entrepreneurial actions and strategies in Brazil. In addition, it may strengthen discussions and the theoretical references of papers addressing the efficiency of Brazilian football clubs. We expect a positive contribution to the football professionalization process in the country.

Right after this introduction, we present a brief discussion on football as a business, as well as a review of previous publications on the theme. Subsequently, we present the methods used in this research and a brief explanation of the tools used (DEA and Tobit regression model). Finally, we present the data found and respective analyses, comparisons with previous findings and final considerations.

\section{LITERATURE REVIEW}

\subsection{FOOTBALL AS A BUSINESS}

Since the 1980s, with the media evolution, football began to receive more interest from large corporations, which envisaged economic opportunities in this sport (PERRUCI, 2006). Dantas and Boente (2011) explain that football began to be viewed as a business when the matches began to be broadcasted on free television, opening an opportunity for sponsors to participate in sportive events. The development of the media and its interest in broadcasting sporting events led marketing professionals to view professional sports as a strong economic opportunity for business (SWEENEY 2007; RATTEN, 2011, 2016). The study conducted by Mellaci, Petrokas and Fáma (2012) showed that sponsoring a football team may yield positive economic returns to the sponsoring company.

The growth of revenues from broadcast ratings, sponsorships, and player trades, among others, have yielded an enormous volume of monetary transactions in football clubs (RIBEIRO; LIMA, 2012). Sports, just as businesses do, contribute to economic activity and the creation of wealth (GOLDMAN; JOHNS, 2009), and a considerable private interest is intent on capitalizing on it, albeit in competition with other leisure activities (BAUER; SAUER; SCHMITT, 2005; RATTEN; RATTEN, 2011). The sports entertainment industry holds football as its main 
cash cow - rightfully so, given its high exposure in the media and the fame of its clubs and athletes. In this way, football remains the most popular form of sports entertainment in Europe (BLUMRODT; DESBORDES; BODIN, 2013).

The revenues earned by Brazilian clubs have been increasing in recent years. Somoggi (2013) illustrated that revenues in the Brazilian market reached $\mathrm{R} \$ 805$ million in 2003, while by 2011 they had reached R $\$ 2.7$ billion - a growth of 335\% in eight years. Revenues stemming from image broadcast rights also grew in that same span of time, and current projections indicate that even higher levels are to be reached: following 2011, when image broadcast rights in Brazil were negotiated collectively via the "Club of the 13" - an organization that represents the largest Brazilian clubs -, such contracts are now made directly between individual clubs and broadcasters (NEVES JÚNIOR et al., 2015).

The Brazilian championship tournament is an economic standout, given that it is the sixth most valuable tournament in the world at a market value of approximately $€ 960$ million (NASCIMENTO et al., 2015). In addition to this, the International Federation of Football History deemed the Brazilian championship of 2012 to be the second greatest in the world, behind the Spanish championship alone (NEVES JÚNIOR et al., 2015).

The growth of activity in this sector of the economy has even brought on changes in legislation and, as a result, the requirements placed on private companies. The Legislative Branch of Brazil has drawn several parallels between professional sports entities and corporations. The eventual classification of professional sports entertainment as an economic activity and the mandatory preparation, and submission to independent auditors, of financial statements, among other factors, led to clubs being viewed as businesses for all intents and purposes (NEVES JÚNIOR et al., 2015).

Internationally, clubs have grown into large companies, gone public and listed in major stock exchanges (DANTAS et al., 2009; DANTAS; BOENTE, 2011). Examples include Tottenham Hottspur and Manchester United, both participating in the Premier League and listed in the London Stock Exchange and New York Stock Exchange, respectively. In 2009, 38 publically traded sporting entities existed in the entire world, meaning that the same would adhere to the corporate model and have their equity traded on the stock market (DANTAS et al, 2009; DANTAS; BOENTE, 2011). In contrast, there is not one Brazilian club with its shares listed on any exchange; however, the current trend is that the management model in use in the private sector is widely used, in order for these to remain competitive as club-companies (NEVES JÚNIOR et al., 2015).

In the eyes of Brazilian fans, it may seem strange to think of their teams as businesses, but not in the view of Robertson and Giulianotti's (2006). According to these authors, football clubs began to work like corporations and became organizations managed by professional teams. Though performance measurement in football clubs was previously based solely on the club's strength in 
the sport itself, the advent of the club-company has brought financial performance to the forefront (DANTAS; MACHADO; MACEDO, 2015). According to Weber (2004), a firm is an organization that performs economically oriented actions towards a goal, based on utilitarian calculations and analysis of consequences in order to maximize the expected returns. Why shouldn't football clubs act this way?

\subsection{TECHNICAL EFFICIENCY}

One of the ways for clubs to be professionalized is being efficient and, to this end, they should use their resources properly. A process is technically efficient when it succeeds in delivering the maximum possible output from a given set of inputs while it minimizes wastefulness (FARREL, 1957). It is possible that an organization becomes efficient by reducing the amount of inputs, keeping the outputs produced/supplied constant (FONCHAMNYO; SAMA, 2014).

Under this perspective, it is necessary to understand that the efficiency rating provided by the DEA model (CHARNES; COOPER; RHODES, 1978) is based on Farrell's efficiency concept (1957). The author sought to establish a production function from observed data and not from an existing production function. According to Farrell (1957), one can see that the efficiency measured by DEA is relative and not absolute - as a firm will be efficient in relation to another firm.

\subsection{FOOTBALL-RELATED PUBLICATIONS}

Like any other business, professional football teams need revenues and profit - or a surplus (positive balance) because, as a rule, clubs are non-profit organizations - to remain competitive in relation to their competitors (opponents). First, it is important to examine what the academy has produced in order for us to analyze aspects relating to the professional management of football clubs.

In international studies about football, works analyzed efficiency with the purpose of identifying variables that would explain the efficiency levels found (HAAS, 2003a, 2003b; BARROS; LEACH, 2006; GUZMÁN; MORROW, 2007; JARDIN, 2009; BARROS; ASSAF; SÁ-EARP, 2010; BARROS; GARCIA-DEL-BARRIO, 2011; SOLEIMANI-DAMANEH; HAMIDI; SAJADI, 2011; KERN; SCHWARZMANN; WIEDENEGGER, 2012; HALKOS; TZEREMES, 2013).

In the national context, Leoncini and Silva (2005) studied the sport professionalization, examined the strategies developed by the clubs and discussed the transformation of their management models. The authors concluded that Brazilian clubs required an effective strategic approach and management professionalization. Mayer (2010) evaluated the strategic planning developed by São Paulo (SP) to become one of the major clubs in the country. Fagundes et al. (2013) and Bazanini et al. (2014) sought to identify which strategies were used to enhance the value of the Corinthians 
brand (SP). The authors highlighted the importance of the entrepreneurial vision of the club's management.

Marques and Costa (2009) concluded that the adoption of Corporate Governance (CG) best practices contributes to improve fundraising by the clubs as well as their management's efficiency and legitimacy. Rezende and Dalmácio (2015) analyzed the relationship between the CG level of Brazilian clubs and the performance level - as a team and in the economic-financial aspects revealing a positive relation between these variables.

Silva and Carvalho (2009) found that the clubs presenting a higher level of publication of financial statements have better on-field outcomes - in the CBF ranking - and in finances Yearly Financial Statement. Rezende, Dalmácio and Salgado (2010) identified that there is little standardization of financial reports by national clubs.

There are studies that measured the efficiency of football clubs using the Data Envelopment Analysis. Firstly, Dantas and Boente (2011) analyzed the financial and sport efficiency with respect to operating expenditures of major international football clubs. The authors concluded that the Manchester United and the Werder Bremen were the most efficient clubs in generating revenues. Afterwards, Dantas and Boente (2012) assessed the expenditure and revenues ratio efficiency of 14 national football clubs and if such expenditures were key to win titles from 2006 to 2009. Finally, Dantas, Machado and Macedo (2015), using financial reports and other financial data from 36 national clubs in the period of 2010 to 2012, showed which are the determinant factors of efficiency of Brazilian clubs. For DEA calculation, they used football expenditures as inputs, and operating revenues and the club's position in the CBF ranking as outputs of this model. Subsequently, using Tobit regression analysis, the authors concluded that the clubs that won titles in a given season as well as the first division clubs are more efficient than the other ones.

"In spite of several decades of extensive academic research on efficiency and its implications in the international context, the empirical findings remain inconsistent and debatable about the causes and effects of efficiency" (BARROS; GARCIA-DEL-BARRIO, 2011, p.5). A noted increase in studies on football club management has taken place in Brazil in recent years, but club efficiency is analyzed by a small portion of scientific investigations (DANTAS; BOENTE, 2011, 2012, DANTAS; MACHADO; MACEDO, 2015), especially in comparison to other regions of the world, such as in Europe and the United States (BARROS; ASSAF; SÁ-EARP, 2010).

In light of this, this study seeks to add to the body of literature on the topic, with the objective of identifying club efficiency and its determinants through methods yet unused toward this particular end by Brazilian academics, among which the clubs' payroll will be used as a component in the efficiency model, and the CBF ranking a possible explanatory variable behind it. 


\section{METHODS}

\subsection{DATA}

The studied universe consists of the 50 best Brazilian football clubs in 2014, according to the CBF ranking published in 2015. All data were obtained from the clubs' financial statements. However, because some data was unavailable or the required information was partially missing, the final sample was reduced to 25 clubs. Table 1 shows how the final sample was constituted.

During data collection, it was found that there is no siting uniformity for the disclosure of the clubs' financial statements. Some statements were available on the State Football Federations' websites, and others only on the clubs' websites. The Federação Paulista de Futebol (São Paulo Football Federation), for example, publishes all data grouped per year and per club on one site only, which increases the transparency of information on the clubs. On the clubs' websites, the display of information varies greatly. Statements were found on tabs such as "The Club", "Properties", "News", "Transparency", among others. Although the clubs transparency is not the aim of this study, we consider it appropriate to highlight this issue, once in future researches one can face the same problem when collecting financial information. We suggest, first, to collect information directly from the federations' websites and, only when information is missing, it should be searched on the clubs' websites.

\subsection{DATA ENVELOPMENT ANALYSIS}

The method used in this study is divided into two stages. In the first one, the Data Envelopment Analysis is used to formulate an efficiency rating of Brazilian football clubs. In this stage, it is possible to know which clubs are references - benchmarks - for other clubs. The DEA model used consists of the Variable Return to Scales (VRS) developed by Banker, Charnes and Cooper (1984), with an orientation to output. The purpose of using this model, in case the clubs are inefficient, is to show how much they can increase their revenues, keeping constant their Total Assets - the sum of all organization's goods and rights - and payroll.

DEA was originally introduced by Charnes, Cooper and Rhodes (1978), based on Farrell's theoretical study (1957). According to Senra et al. (2007), it is a technique based on linear

Table 1. Clubs included in the research.

\begin{tabular}{ll}
\hline 50 Best Clubs - Universe & 50 \\
\hline (-) Clubs that did not publish the Financial Statements for all periods & 15 \\
(-) Clubs that published the Financial Statements, but with embodied information, preventing an effective analysis & 10 \\
(=) Final balance of the analyzed clubs & 25 \\
\hline
\end{tabular}
Source: Research data (2015). 
programming, which has the objective of measuring the performance of decision making units (DMU).

According to Charnes and Cooper (1985), DEA aims to know which organizations are capable of producing certain levels of outputs from the same level of inputs, or certain levels of inputs with the same level of outputs. By knowing such an ability, a set of references can be built, which allows ranking DMUs as efficient or inefficient units. As a reference, the surface formed by this set is used, the efficient units being located above the frontier and the inefficient ones below the frontier.

DEA has two traditional models commonly used, which are the Constant Return to Scales (CRS) and the Variable Return to Scales (VRS). The latter considers variable return scales in its mathematical programming, permitting that decision making units that operate with low level of inputs have increasing returns to scale, and that units with high inputs levels have decreasing returns to scale (MELLO et al., 2003). A limitation of using VRS is that the model often produces a larger number of efficient DMUs than the CRS does, diminishing their discriminating ability.

\subsection{INPUTS AND OUTPUTS}

Assorted researchers have evaluated club efficiency from different points of view, ranging from economic to sports-based (KULIKOVA; GOSHUNOVA, 2014). In this paper, efficiency is viewed through the economics of the club alone.

Table 2 shows the inputs and outputs used in the DEA. The variables are similar to those used in the study conducted by Barros and Garcia-Del-Barrio (2011). Some adaptations were necessary because of the poor level of details found in the Brazilian clubs' financial statements.

The club's efficiency is measured by its ability to use its total assets and the remuneration of all employees - payroll - to generate revenues, compared to other clubs. Again, it should be noted that the efficiency measured by DEA is relative. Thus, even if the club achieves the desired efficiency with the proposed model, it can improve the inputs and outputs ratio.

It merits attention that this is not the only way to measure club efficiency, for it can vary as a result of the selection of model inputs and outputs. An adequate choice of these variables is a

Table 2. Variables used in DEA application.

\begin{tabular}{lccc}
\hline Inputs & Description & Outputs & Description \\
\hline Total Assets & $\begin{array}{c}\text { It consists of the sum of all firm's goods and } \\
\text { rights }\end{array}$ & $\begin{array}{c}\text { Total gross revenues before } \\
\text { deducting sales tax (income } \\
\text { from professional and } \\
\text { amateur football) }\end{array}$ \\
\hline
\end{tabular}

Total labor costs (salaries, social contributions

Payroll and benefits) of the club' personnel

(professional and amateur)

Source: Adapted from Barros and Garcia-Del-Barrio (2011). 
fundamental part of the application of DEA. In the model proposed herein, inputs are represented by the total assets and talent stock of the clubs under analysis. This occurs, since both are believed to be important for the generation of revenues; those clubs with larger stadiums will have a greater opportunity to employ that asset toward cash flows. Nevertheless, using the size of the stadium alone leaves out other key characteristics such as intangible assets and other investments that the club may possess. In light of this, total assets, instead of specific asset values, was deemed a more telling indicator.

Player salaries can be viewed as a proxy for the talent stock held by any one club. More popular players stand to bring in more revenues, whether through attracting more fans to attend games or increasing merchandise sales volumes. Though the club payroll might not be the perfect proxy for the talent stock, it is the closest one to it (JARDIN, 2009), especially in the case of Brazilian clubs.

International studies on this topic used labor costs to measure the clubs' efficiency (HAAS, 2003a, 2003b, JARDIN, 2009, BARROS; GARCIA-DEL-BARRIO, 2011). However, often only the players remuneration is used (BARROS; LEACH, 2006) or the players and coach remuneration (HAAS, 2003a, 2003b). However, because of the difficulty in obtaining this information from the balance sheets of Brazilian clubs (most of them do not disclose it), we decided to use the total payroll, including the salaries of all employees and players of the club.

From the economic point of view, one of the primary outputs in the literature is revenues (HAAS, 2003a, 2003b, BARROS; LEACH, 2006, GUZMÁN; MORROW, 2007, JARDIN, 2009, BARROS; GARCIA-DEL-BARRIO, 2011), which is generally assessed in gross, in place of net, amounts. The use of this variable is suitable to the scenario in which Brazilian football clubs currently operate, given that they edge closer and closer to characteristics otherwise thought as inherent to the private sector (JARDIN, 2009). In the present study, the use of revenues at the disaggregated level would imply a considerable reduction in sample size, for many clubs do not disclose at that level of detail in their respective financial statements. For this reason, the total club revenues were employed in analyses.

As such, the following factors most taken into consideration when selecting these variables can be noted: the existing theoretical framework on the topic, the availability of data, and the impact of club efficiency variables that are largely overlooked by Brazilian academia as of yet.

\subsection{TOBIT REGRESSION}

At the second stage of the research, a Tobit regression model was generated with the purpose of knowing which variables have influence on the clubs efficiency. Hoff (2007) comments that the Tobit regression model should be used when the dependent variable is concentrated at some of the 
limiting points or in between the frontier values. Sueyoshi, Goto and Omi (2010) consider it the natural second stage of DEA, due to the truncated feature of the efficiency variable. According to the authors, as the efficiency measured by DEA ranges from score 0 to 1 , the use of the ordinary least squares methods would be flawed, because the resulting parameters would be inconsistent and biased. Tobin (1958) comments that the estimates of the Tobit regression model, or censored regression, must be achieved by the maximum likelihood method.

The Tobit regression model presented in this research considers as the dependent variable the clubs efficiency rating, as obtained by the application of DEA in the periods under analysis. The independent variables are formed by quantitative and qualitative data.

Due to the qualitative feature of some of these variables, this information was treated as dummy variables, assuming score 0 for negative responses and score 1 for positive responses. According to Wooldridge (2008), dummy variables - or binary variables - are ways to aggregate qualitative information to statistical regression models. For this, it is necessary to define which event will be scored 0 and which one will be scored 1 .

For example, if the club did not win titles in the period under analysis, the variable will be scored 0 in the analysis. On the other hand, if the club won one title in the period of analysis, the variable will be scored 1 .

The independent variables (dummy variables) of this model are the following:

- Titles - Clubs that won titles (state, national or international) in the time period or not;

- Division - Serie A Teams of the Brazilian Championship or not;

- 12 major clubs - the 12 best clubs according to the CBF ranking in each year of analysis or other clubs;

- Access to a higher level or Libertadores - Promoted to Serie A of the Brazilian championship / granted a place in the Libertadores Cup or others;

- Relegated - Teams that have dropped from Series A, B or C in Brazilian championships or others;

- Unsecured liabilities - Clubs with unsecured liabilities or not;

- $\quad$ Rating in the CBF ranking.

The variables used in the Tobit regression model are similar to those used by Dantas, Machado and Macedo (2015), with the exception of the seventh variable (Rating in the CBF ranking). This variable was introduced to the Tobit regression model to determine whether the CBF rating had an influence on the clubs' efficiency. This variable serves as a proxy variable to determine the "quality" of the clubs.

Positive signs are expected for the Titles, Division, 12 Major Clubs, Access or Libertadores and Rating in the CBF ranking variables; after all, a priori, these conditions should contribute 
toward greater efficiency, on part of the clubs. In contrast, negative signs are expected for the Relegated and Unsecured Liabilities variables. The Relegated variable may indicate that the club has not succeeded in achieving satisfactory outcomes on the playing field, whereas the Unsecured Liabilities variable may indicate that the club is at an unfavorable financial situation, once the club's total payable liabilities exceed total assets. The Relegated and Unsecured Liabilities may indicate poor management of the club; therefore, it is expected that the variables have a negative influence on the efficiency of the clubs.

We used the SIAD v. 3 software for the calculation of DEA and the Gretl v. 1.9.92 software for the calculation of the Tobit regression model.

\section{RESULTS}

\subsection{MEASURING EFFICIENCY THROUGH DEA}

The first stage of the study is to rate the efficiency of the major Brazilian football clubs. After collecting and tabulating the data, all residuals were analyzed for the period of the research by means of multiple regression, using the clubs' Total Gross Revenue as the dependent variable. Flamengo (RJ), in 2014, and São Paulo, in 2013, presented 2.5 times more residuals than the standard deviation. This could indicate that both clubs would be outliers of the sample; however, because they are relevant clubs in the national scenario and because such exclusion is not a DEA requirement, we decided to keep them in the analysis.

Table 3 presents the clubs' efficiency rating in 2012, 2013 and 2014 and the necessary revenues increase that the inefficient clubs should ensure to achieve efficiency.

According to Table 3, although 15 clubs were placed at the efficiency frontier $($ efficiency $=1)$ in 2012, there are clubs that stand out among others. This can be observed by the number of times that they were benchmarks for other clubs. The two clubs that were references more frequently for other clubs were São Paulo - 8 times for Avaí, Coritiba, Cruzeiro, Fluminense, Grêmio, Palmeiras, Vasco and Ponte Preta, and Santos - 6 times for Atlético (GO), Avaí, Cruzeiro, Grêmio, Palmeiras and Vasco.

It is worth noting that among the efficient teams, there are clubs that were in Serie A of the Brazilian championship - Atlético (MG), Botafogo, Corinthians, Flamengo, Internacional, Santos and São Paulo; in Serie B - ASA, Atlético (PR), Bragantino, Goiás, Guarani, Guaratinguetá and Joinville; and in Serie C - Oeste.

Although the club did not achieve the efficiency level, Fluminense was champion of the national Brazilian league in 2012, followed by Atlético (MG), Grêmio and São Paulo. One possible explanations for Fluminense not being efficient in this period is that the club paid high salaries to 
Table 3. Efficiency, Current Revenues and Targeted Revenues in 2012, 2013 and 2014 fiscal year.

\begin{tabular}{|c|c|c|c|c|c|c|c|c|c|}
\hline \multirow[b]{2}{*}{ Club } & \multicolumn{3}{|c|}{2014} & \multicolumn{3}{|c|}{2013} & \multicolumn{3}{|c|}{2012} \\
\hline & Eff. & $\begin{array}{c}\text { Current } \\
\text { Revenue }^{\mathrm{a}}\end{array}$ & $\begin{array}{l}\text { Targeted } \\
\text { Revenue }^{\mathrm{a}}\end{array}$ & Eff. & $\begin{array}{c}\text { Current } \\
\text { Revenue }^{\mathrm{a}}\end{array}$ & $\begin{array}{c}\text { Targeted } \\
\text { Revenue }^{\mathrm{a}}\end{array}$ & Eff. & $\begin{array}{c}\text { Current } \\
\text { Revenue }^{\mathrm{a}}\end{array}$ & $\begin{array}{l}\text { Targeted } \\
\text { Revenue }\end{array}$ \\
\hline ASA (AL) & 0.49 & 3959 & 8068 & 1.00 & 8425 & 8425 & 1.00 & 6141 & 6141 \\
\hline Atlético (GO) & 1.00 & 83969 & 83969 & 0.34 & 10542 & 30758 & 0.44 & 23408 & 53573 \\
\hline Atlético (MG) & 1.00 & 178942 & 178942 & 1.00 & 227863 & 227863 & 1.00 & 162963 & 162963 \\
\hline Atlético (PR) & 1.00 & 102230 & 102230 & 1.00 & 74314 & 74314 & 1.00 & 56910 & 56910 \\
\hline Avaí (SC) & 1.00 & 30157 & 30157 & 0.94 & 19192 & 20429 & 0.40 & 23209 & 57600 \\
\hline Botafogo (RJ) & 1.00 & 157913 & 157913 & 1.00 & 174848 & 174848 & 1.00 & 119001 & 119001 \\
\hline Bragantino (SP) & 1.00 & 9724 & 9724 & 1.00 & 8663 & 8663 & 1.00 & 10508 & 10508 \\
\hline Corinthians (SP) & 1.00 & 217179 & 217179 & 1.00 & 316023 & 316023 & 1.00 & 358512 & 358512 \\
\hline Coritiba (PR) & 0.41 & 87283 & 211821 & 0.53 & 96698 & 183072 & 0.44 & 82757 & 187610 \\
\hline Cruzeiro (MG) & 1.00 & 223162 & 223162 & 1.00 & 187869 & 187869 & 0.45 & 120363 & 266051 \\
\hline Flamengo (RJ) & 1.00 & 347027 & 347027 & 1.00 & 272999 & 272999 & 1.00 & 212019 & 212019 \\
\hline Fluminense (RJ) & 0.69 & 122271 & 177685 & 0.76 & 124760 & 163156 & 0.84 & 151177 & 179503 \\
\hline Goiás (GO) & 1.00 & 66719 & 66719 & 1.00 & 55472 & 55472 & 1.00 & 53114 & 53114 \\
\hline Grêmio (RS) & 0.73 & 191182 & 259921 & 0.68 & 167359 & 244985 & 0.83 & 177811 & 213540 \\
\hline Guarani (SP) & 1.00 & 3884 & 3884 & 1.00 & 16423 & 16423 & 1.00 & 26722 & 26722 \\
\hline Guaratinguetá (SP) & 1.00 & 10308 & 10308 & 1.00 & 1524 & 1524 & 1.00 & 1928 & 1928 \\
\hline Internacional (RS) & 0.88 & 205086 & 233278 & 1.00 & 259581 & 259581 & 1.00 & 252861 & 252861 \\
\hline Joinville (SC) & 0.69 & 28674 & 41711 & 1.00 & 21917 & 21917 & 1.00 & 15122 & 15122 \\
\hline Oeste (SP) & 1.00 & 3397 & 3397 & 1.00 & 1950 & 1950 & 1.00 & 1931 & 1931 \\
\hline Palmeiras (SP) & 0.75 & 202717 & 269808 & 0.66 & 176881 & 266755 & 0.89 & 241154 & 269780 \\
\hline Paraná (PR) & 0.17 & 17011 & 98693 & 0.78 & 52126 & 67003 & 0.43 & 18478 & 43133 \\
\hline Ponte Preta (SP) & 0.31 & 22416 & 71384 & 0.72 & 45584 & 63228 & 0.34 & 30100 & 87768 \\
\hline Santos (SP) & 1.00 & 169938 & 169938 & 1.00 & 190275 & 190275 & 1.00 & 197837 & 197837 \\
\hline São Paulo (SP) & 0.82 & 253381 & 308465 & 1.00 & 362832 & 362832 & 1.00 & 319106 & 319106 \\
\hline Vasco (RJ) & 0.54 & 129194 & 239636 & 0.58 & 159704 & 272784 & 0.67 & 146187 & 236977 \\
\hline
\end{tabular}

Source: Research data (2015).

${ }^{\mathrm{a}}$ in thousand Reais (BRL).

the players without having a proportional increase in revenues. This situation helped lead the club to win the national title but not to the desired efficiency. In the following years, however, the club failed to get a national or state title.

The ASA, Corinthians, Flamengo and São Paulo teams were also considered efficient clubs in 2012 according to the work conducted by Dantas, Machado and Macedo (2015). However, Atlético (MG), Atlético (PR), Botafogo, Bragantino, Goiás, Guarani, Internacional, Joinville and Santos were considered inefficient, and Guaratinguetá was not part of the sample of these authors' study. Such considerations require a careful analysis because the variables used and the sample analyzed by the authors are different from the sample of the present study. 
By analyzing the clubs' efficiency levels, according to Table 3 in 2013, one can see that the major national football clubs such as Fluminense, Grêmio, Palmeiras and Vasco did not succeed in being efficient in this period.

Still in the year 2013, 16 clubs composed the list of efficient teams. However, the teams that were most used as benchmarks by other clubs were Bragantino - 7 times for Atlético (GO), Avaí, Coritiba, Fluminense, Palmeiras, Paraná and Ponte Preta; São Paulo - 6 times for Coritiba, Fluminense, Grêmio, Palmeiras, Paraná and Vasco; and Botafogo - 5 times for Atlético (GO), Coritiba, Grêmio, Palmeiras and Vasco. These references can be useful for the clubs that were not efficient, mirroring in the practices adopted by their respective benchmarks.

In 2012, Cruzeiro was inefficient (0.4524) and at the time it was suggested that the club's revenues should rise to BRL 266 million. In 2013, the club reached a total of BRL 187 million in revenues, but it was enough to make it efficient. In the same year, the club won the title of the Brazilian championship, repeating the success in 2014.

In 2014, one can see that several clubs were inefficient in generating revenues in the period under analysis, particularly the Paraná club, which achieved an efficiency rate of 0.1724 only, i.e., the club reached only $17 \%$ of the revenues required to make it efficient. We can observe that the club had a considerable reduction of revenues in the year 2013 compared to 2014, from BRL 52 million to BRL 17 million. Since it fell to Serie B in 2007, the club did not succeed in being promoted to Serie A, ranging from the $7^{\text {th }}$ and $11^{\text {th }}$ position in the final ranking of Serie $B$. The club did not win any state title in the period.

Only Atlético (MG), Atlético (PR), Botafogo, Bragantino, Corinthians, Flamengo, Guarani, Guaratinguetá, Oeste and Santos remained efficient in the periods under analysis. All the other clubs were inefficient at least in one period. Vasco, Palmeiras and Grêmio were big teams that did not reach efficiency in any period.

Vasco did not win any state or national title during 2012-2014, the team was relegated to Serie B in 2013 and promoted to Serie A again in 2014. Recently, in 2015, Vasco won the Rio de Janeiro championship for the twenty-third time. Grêmio had a similar performance, i.e., it did not win any national or state title in the period. However, it was the only club not relegated from Serie A, and earned a place in the Libertadores Cup for two consecutive years (2012 and 2013). Palmeiras was relegated to Serie B in 2012 and champion of the Brazil Cup in the same year. In 2013, this team won the Brazilian Serie B championship. However, the club did not win any state titles.

Out of all the clubs that comprise the sample, Internacional was the only one that remained efficient during the period of analysis (2006 to 2009), according to the study by Dantas and Boente (2012). However, in the present research, the club did not succeed in reaching efficiency in 2014. 


\subsection{EFFICIENCY DETERMINANTS VIA TOBIT REGRESSION}

The results obtained from the Tobit regression model presented the following results, as shown in Table 4. Robust standard errors were not used in the proposed model and corner restrictions were not inserted.

As can be seen in Table 4, Titles, Division and Rating in the CBF ranking were the only statistically significant variables. However, the sign of Rating in the CBF ranking is the opposite of that initially expected. The sign indicates that the higher the score in the ranking, the less efficient the club is. Initially, we expected that the first clubs in the ranking would be the most efficient, since they are the ones achieving better results on the field. Thus, either the results are inconsistent or the best Brazilian clubs actually tend to be less efficient. On the other hand, the signs obtained from the coefficients of Titles and Division variables in principle are as expected, indicating that the Serie A clubs and the conquest of titles have influence on the clubs' efficiency.

According to the Variance Inflation Factors (VIF) values, none of the independent variables presented multicollinearity problems. Even though we were aware that the methodology used in the $\mathrm{CBF}$ ranking takes into account the conquest of titles, we decided to maintain both variables in the Tobit regression model once the VIF did not indicate any collinearity problem between the variables. Moreover, we believe that the addition of the CBF ranking in the Tobit model is vital to know the impact of the club quality on its efficiency.

Finally, Graph 1 shows the relationship between the Efficiency variable and CBF ranking.

By analyzing Graph 1, we can see that there is a trend, although not significant, between the inefficient teams and the CBF ranking. However, when we analyze only the clubs that reached the top level of efficiency (1.00), this trend is not apparent. We believe that such variable is vital and should be examined more carefully in future works.

Table 4. Results from the Tobit regression model.

\begin{tabular}{lccccc}
\hline Variable & Coefficient & Standard & Z & P-value & Significance $^{\mathrm{a}}$ \\
\hline Constant & 0.918 & 0.097 & 10.000 & $1.45 \mathrm{e}-23$ & $* * *$ \\
Titles (dummy) & 0.114 & 0.046 & 2.127 & 0.033 & $* *$ \\
Division (dummy) & 0.159 & 0.116 & 1.733 & 0.083 & $*$ \\
12 Major Clubs (dummy) & 0.138 & 0.108 & 1.516 & 0.130 & \\
Promoted or earned a place in Libertadores (dummy) & 0.051 & 0.061 & 0.814 & 0.416 & \\
Relegated (dummy) & -0.00893800 & 0.081 & -0.106 & 0.915 & \\
Unsecured Liabilities (dummy) & 0.040 & 0.057 & 0.748 & 0.455 & \\
Rating in the CBF ranking & $-3.114 \mathrm{e}-05$ & $1.16 \mathrm{e}-05$ & -2.537 & 0.011 & $* *$ \\
\hline
\end{tabular}

Source: Research data (2015).

${ }^{a}$ About the statistical significance sign, an asterisk indicates a 10\% significance level, two asterisks indicate a 5\% significance level and three asterisks refer to a $1 \%$ significance level. 


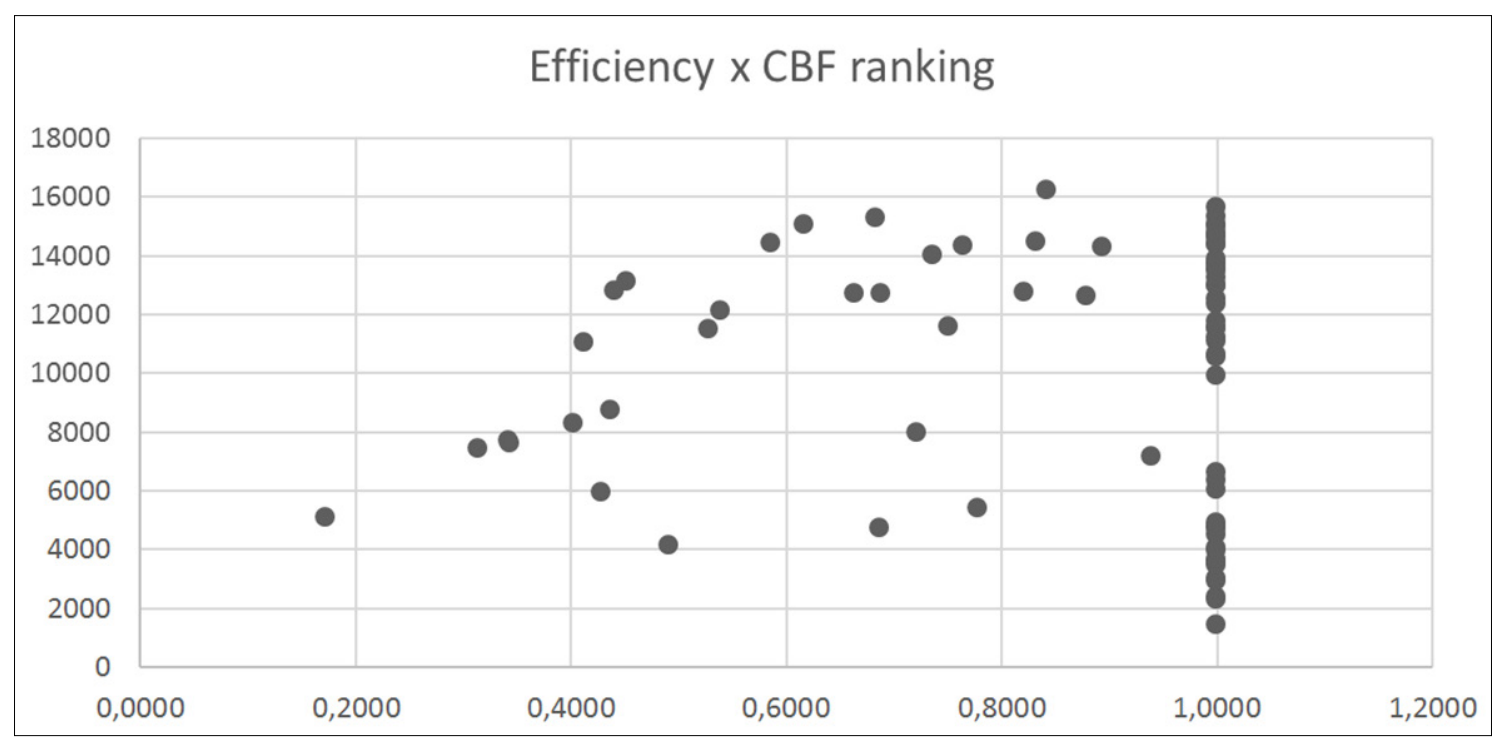

Source: Research data (2015).

Graph 1. Dispersion between Efficiency and the CBF ranking.

Graph 1 is also important to show the reason for using Tobit instead of multiple regression, once there is clearly a great concentration of dots in one of the corners (1).

\section{DISCUSSION}

Low levels of efficiency in Brazilian football clubs were observed by Barros, Assaf and SáEarp (2010). Still, such levels have undergone an increase in recent years (DANTAS; MACHADO; MACEDO, 2015), thus, signaling possible improvements made in managerial techniques in Brazilian clubs. In the present study, average efficiency was shown to be 0.83 in 2012, 0.88 in 2013, and 0.82 in 2014. Despite this, larger clubs were not able to adequately mobilize their resources toward greater efficiency. More specifically, inconsistencies were found between total assets and the talent stock, and club revenues.

A case of particular note is Fluminense, which became champion of the national Brazilian league in 2012, despite being economically inefficient in the same year. This fact can bring important insight into strategic management in football, given that the long-term relationship between performance in finances and on the field has been illustrated in the literature, with marked attention to the importance of joining the two (BARROS; ASSAF; SÁ-EARP, 2010). Financial sacrifices might work in the short term, but it also stands to yield negative consequences in the future; we once again make reference to Fluminense, the organization did not win any state or national titles after the 2012 championship. Regardless, only an analysis on a longer timeline can assist in a more precise identification of these trends. 
In order to improve club efficiency, Brazil must overcome certain structural and cultural problems, e.g. relatively low ticket sales revenues, especially in comparison to those of European clubs (BARROS; ASSAF; SÁ-EARP, 2010). To attract families and a target market of greater purchasing power ought to be one of managers' objectives. To achieve this, fans must be made to see the stadium as a public place of entertainment (MAYER, 2010). This will require joint efforts between the fan base, public institutions, law enforcement and managers, in order to change stadium culture and create an adequate environment for children and families to enjoy games without worrying for safety and security.

Another factor that can interfere in football patronage is the time of day at which games are played on weekdays, which are generally late in the evening. In addressing this, Real Madrid proposed that its games take place earlier, so that Chinese fans could watch them (RATTEN; RATTEN, 2011). Whether or not current game times are suitable to clubs' managerial needs is yet to be determined.

The maximization of stadium use is one of the main changes that has taken place in the 21 st century. However, another matter of importance is the fact that stadiums have also become a popular tourist attraction in many cities, especially in Europe (GINESTA, 2016). Consequently, making Brazilian stadiums into tourism mainstays should factor into managers' strategies.

Integrating other products to football also stands to bolster club finances, as was the case of Real Madrid, which built a hotel beside its stadium, and Barcelona FC, which recently erected a sports complex on more than 20 hectares (GINESTA, 2016). Further, Barcelona FC uses its website to promote its stadium, offering, among other things, its stadium as a set for filming movies (GINESTA, 2016). Can all this be a faraway reality for Brazilian clubs?

As efficiency, for the purposes of the present study, also takes club talent stock into consideration, commercializing player celebrity can also be a fundamental building block of club efficiency. Celebrity athletes can be a driver of the consumption of products related to football clubs (RATTEN, 2016), increasing team revenues. However, some of these athletes often receive tremendous salaries; the cost-benefit analysis of these contracts should be carefully considered in order to prevent an expense out of proportion to future financial benefits.

From this, it can be gathered that inefficient clubs might make use of benchmarks, in order to better understand how those clubs are managed and, subsequently, make improvements. As the revenue levels to be reached were highlighted, these can serve as goals for inefficient clubs to attain in the future. The literature points out that other characteristics of efficient clubs can be observed, including how they organize their sports marketing (CUNHA et al., 2015, RATTEN, 2016) and their quality of governance (MARQUES; COSTA, 2009, REZENDE; DALMÁCIO, 2015). 
The results found through the Tobit regression modeling also encourage discussion that could serve to improve strategic planning in football clubs.

Justification for the sign of Rating in the CBF could be based on the fact that clubs with good on-field results tend to have highly-compensated players: efficiency would drop if revenues did not grow along with salaries. On the other hand, the results pertaining to the variables Titles and Division are consistent with those found by Dantas, Machado and Macedo (2015). This may indicate that these variables are important to influence the football clubs' efficiency. Some factors that can be related to this is that the Serie A teams and the clubs that win more titles usually have more prominence in the media. In addition, they receive more funds from $\mathrm{CBF}$, making them more susceptible to the demands of society, fans and the government.

With the relationship between efficiency, titles, and football elites, changes in strategy may be necessary for some clubs to improve their performance both on and off the field. The characteristics of private companies become more necessary on-field, without neglecting the possibility of these clubs having their shares traded on the stock exchange. This would engender increased professionalism, greater transparency, and, as a result, more efficiency.

\section{FINAL CONSIDERATIONS}

In order for Brazil to continue being recognized as an international reference to football, it is vital that managers and related entities make this sport more professional off the playing field. Such professionalization process may take place through a series of changes such as more transparency in the clubs management, creation of more strict laws and a more effective use of the resources available. To this end, academic studies that would seek to measure efficiency and indicate its causes are necessary.

The results show that the major Brazilian clubs did not succeed in being efficient in any of the periods examined. Such results may be a source of useful information to the managers of these clubs, considering that the value of the revenues that they should have accomplished was presented. We found that the Titles and Division variables are key to determine the efficiency or inefficiency of a team. The findings are in agreement with those found by Dantas, Machado and Macedo (2015). The Rating in the CBF Ranking variable, although significant in the Tobit regression model, presented an opposite sign to the one expected, so it should be examined carefully.

In general terms, several insights can be drawn from Mayer (2010)'s work on the causes maximizing the revenues of the largest European clubs, such as the adoption of marketing practices - held for much longer than in Brazil -the higher purchasing power of their fans, a greater number of star personalities and potential high-quality matches to the expectations of the fans. One way to increase revenues would be by "diversifying the sources of revenues by offering an increasing mix 
of products and services to their fans and others" (MAYER, 2010, p. 66) (author's translation), such as the rental of their premises for shows, events and even wedding ceremonies.

The clubs that would not be able to achieve the desired efficiency could adopt some of these practices. By taking Mayer (2010)'s findings into consideration, it is possible that the practices adopted by São Paulo FC - the club analyzed by the author - may be reproduced by inefficient clubs, since this team was efficient in 2012 and 2013 according to the present study. In order to improve their own managerial acumen, managers can view benchmarks as a way to size up how these clubs manage their operations. Various suggestions for growing club revenues can be noted in the discussion section of this paper.

Proper measurement of efficiency in this research depends on reliable financial statements to represent the clubs' reality properly. However, some authors have commented on the lack of standard of financial statements published by some clubs (REZENDE; CUSTÓDIO, 2012, GALVÃO; MIRANDA, 2016), a high number of financial statements with adverse comments by independent auditors (GALVÃO; VASCONCELOS, 2015) and low levels of corporate governance (REZENDE; DALMÁCIO, 2015). Thus, such limitations may influence the research results and must be taken into consideration when interpreting the conclusions presented.

The study conducted here joins previous studies on strategic planning in football, particularly on efficiency analysis. Decades of international empirical research still displays contradictory results; in Brazil, the literature on the topic is on the rise, thus demonstrating the increased interest in the topic by academics. One contribution to developing theory is the negative significance found between the $\mathrm{CBF}$ ranking and club efficiency; the counter-intuitive behavior of these two variables presents the possibility of further analysis in subsequent research.

Finally, the findings present a dilemma to the Brazilian clubs. To be efficient, the club should aim to winning titles and standing out among the top football teams; however, to achieve this goal, investments are necessary, but this may otherwise generate inefficiency, creating a vicious circle. Thus, it is possible to state that without profound changes, many clubs will have difficulties in finding a balance between off-field efficiency and satisfactory on-field results and, consequently, remain among the best national teams.

Suggestion for future researches includes the application of the method used in the present study only for the football clubs that have their financial reports audited by independent auditors. The recent publication of Law no. 13.155, dated August 2015, and with PROFUT implementation, a greater number of clubs may be audited, once this program requires that the clubs that are willing to join the program follow this procedure. 
The lack of standard in the presentation of financial statements may also be the focus of future studies, once current laws do not indicate where the clubs should publish their financial reports. Even so, standard is vital for other studies that have the same objective of the present research.

Additional studies that can potentially contribute to the literature are highlighted by Ratten and Ratten (2011). These include a case study on the internationalization of football teams, or, rather, the capacity for clubs to gain recognition for their brands overseas. The authors go on to suggest that club efficacy in capitalizing on the celebrity of their players, thus supporting the development of their brand, be taken into consideration. This is especially true in the case of Brazil, indicating the large growth potential for future research in this field.

\section{REFERENCES}

ANDRADE, D. C. T.; RAMOS, H. R. Futebol: paixão ou negócios? Uma análise da produção científica mundial. PODIUM Sport, Leisure and Tourism Review, v. 4, n. 3, p. 169-184, 2015.

BANKER, R. D.; CHARNES, A.; COOPER, W. W. Some models for estimating technical and scale inefficiencies in data envelopment analysis. Management Science, v. 30, n. 9, p. 10781092, 1984.

BARROS, C. P.; ASSAF, A.; SÁ-EARP, F. Brazilian football league technical efficiency: A Simar and Wilson approach. Journal of Sports Economics, v. 11, n. 6, p. 641-651, 2010.

BARROS, C. P.; GARCIA-DEL-BARRIO, P. Productivity drivers and Market dynamics in the Spanish first division football league. Journal of Productivity Analysis, v. 35, n. 1, p. 5-13, 2011.

BAUER, H. H.; SAUER, N. E.; SCHMITT, P. Customer-based brand equity in the team sport industry. European Journal of Marketing, v. 39, n. 5/6, p. 496-513, 2005.

BARROS, C. P.; LEACH, S. Analyzing the performance of the English F.A. Premier League with an Econometric Frontier Model. Journal of Sports Economics, v. 7, n. 4, p. 391-407, 2006.

BAZANINI, R.; SANTOS, R. B.; RIBEIRO, H. L.; BAZANINI, H. L. Empreendedorismo na sociedade do espetáculo: gestão do futebol no universo globalizado. Perspectivas em Gestão \& Conhecimento, v. 4, n. 1, p. 135-160, 2014.

BLUMRODT, J.; DESBORDES, M.; BODIN, D. Professional football clubs and corporate social responsibility. Sport, Business and Management: An International Journal, v. 3, n. 3, p. 205-225, 2013.

CHARNES, A.; COOPER, W. W. Preface to topics in data envelopment analysis. Annals of Operations Research, v. 2, n. 1, p. 59-94, 1985.

CHARNES, A.; COOPER, W. W.; RHODES, E. Measuring the efficiency of decision-making units. European Journal of Operational Research, v. 2, n. 6, p. 429-444, 1978.

CUNHA, E. C. M.; SILVA, V. H. R.; PEDROSO, C. A. M. Q.; BARROS FILHO, M. A.; SANTOS, A. A. R.; MIRANDA, Y. H. B. Influências da gestão e do marketing esportivo no desenvolvimento de ações e estratégias para o futebol como negócio no Brasil: uma revisão sistemática. Revista Intercontinental de Gestão Desportiva, v. 5, n. 2, p. 143-152, 2015. 
DANTAS, M. G. S.; BOENTE, D. R. A eficiência financeira e esportiva dos maiores clubes de futebol europeus utilizando a Análise Envoltória de Dados. Revista de Contabilidade e Organizações, v. 5, n. 13, p. 75-90, 2011.

DANTAS, M. G. S.; BOENTE, D. R. A utilização da Análise Envoltória de Dados na medição de eficiência dos clubes brasileiros de futebol. Contabilidade Vista \& Revista, v. 23, n. 2, p. 101-130, 2012.

DANTAS, M. G. S.; MACHADO, M. A. V.; MACEDO, M. A. S. Fatores determinantes da eficiência dos clubes de futebol do Brasil. Advances in Scientific and Applied Accounting, v. 8, n. 1, p. 113-132, 2015.

DANTAS, M. G. S.; SILVA, J. A.; STEPPAN, A. I. B.; OLIVEIRA, R. M. A. O comportamento do preço das ações de clubes mediante a variação de aspectos contábeis: o estudo de caso do Juventus F.C. - Itália. Revista Ambiente Contábil, v. 1, n. 2, p. 55-67, 2009.

FAGUNDES, A. F. A.; VEIGA, R. T.; SAMPAIO, D. O.; SOUSA, C. V.; SANTANA, É. E. P.; LARA, J. E. Um estudo sobre a satisfação do consumidor esportivo que frequenta estádios de futebol em Belo Horizonte. RECADM, v. 12, n. 1, p. 121-135, 2013.

FARREL, M. The measurement of productive efficiency. Journal of the Royal Statistical Society, V. 120, 253-281, 1957.

FLACH, L.; MÜLLER, M. M. Apresentação de um modelo de regressão múltipla para o disclosure de ativos intangíveis. CONTABILOMETRIA - Brazilian Journal of Quantitative Methods Applied to Accounting, v. 1, n. 2, p. 36-51, 2014.

FONCHAMNYO, D. C.; SAMA, M. C. Determinants of public spending efficiency in education and health: evidence from selected CEMAC countries. Journal of Economics and Finance, p. $1-12,2014$.

FREY, I. A.; CUNHA, R. Z. Demonstrações contábeis dos clubes de futebol do campeonato catarinense de 2012: verificação da adequação à legislação vigente. Revista Eletrônica do Alto Vale do Itajaí, v. 3, n. 4, p. 12-24, 2014.

GALVÃO, N. M. S.; MIRANDA, L. C. Participação e evidenciação de atletas nos demonstrativos contábeis de clubes de futebol brasileiro. Gestão, Finanças e Contabilidade, v. 6, n. 1, p. 112$131,2016$.

GALVÃO, N. M. S.; VASCONCELOS, A. L. F. S. Ressalvas recorrentes nos relatórios de auditoria dos clubes de futebol. Revista de Contabilidade UFBA, v. 9, n. 1, p. 73-92, 2015.

GOLDMAN, M.; JOHNS, K. Sportainment: changing the pace of limited-overs cricket in South Africa. Management Decision, v. 47, n. 1, p. 124-136, 2009.

GUZMÁN, I.; MORROW, S. Measuring efficiency and productivity in professional football teams: evidence from the English Premier League. Central European Journal of Operations Research, v. 15, n. 4, p. 309-328, 2007.

GINESTA, X. The business of stadia: maximizing the use of Spanish Football venues. Tourism and Hospitality Research, Pre-published on May, 2016.

HAAS, D. J. Productive efficiency of english football teams: A Data Envelopment Analysis approach. Managerial and Decision Economics, v. 24, n. 5, p. 403-410, 2003 a.

HAAS, D. J. Technical efficiency in the Major League Soccer. Journal of Sports Economics, v. 4, n. 3, p. 203-215, 2003 b. 
HALKOS, G.; TZEREMES, N. A Two-Stage Double Bootstrap DEA: The Case of the Top 25 European Football Clubs' Efficiency Levels. Managerial and Decision Economics, v. 34, n. 2, p. 108-115, 2013.

HOFF, A. Second stage DEA: Comparison of approaches for modelling the DEA score. European Journal of Operational Research, v. 181, n. 1, p. 425-435, 2007.

JARDIN, M. Efficiency of french football clubs and its dynamics. Munich Personal RePEc Archive, n. $19.828,2009$.

KERN, A.; SCHWARZMANN, M.; WIEDENEGGER, A. Measuring the efficiency of English Premier League football. Sport, Business and Management: an International Journal, v. 2, n. 3, p. 177-195, 2012.

KULIKOVA, L. I.; GOSHUNOVA, A. V. Efficiency measurement of professional football clubs: a non-parametric approach. Life Science Journal, 2014, v. 11, p. 117-122, 2014.

LAMPE, H. W.; HILGERS, D. Trajectories of efficiency measurement: a bibliometric analysis of DEA and SFA. European Journal of Operational Research, v. 240, n. 1, p. 1-21, 2015.

LEITE, D. U.; PINHEIRO, L. E. T. Disclosure de ativo intangível: um estudo dos clubes de futebol brasileiros. Enfoque: reflexão contábil, v. 33, n. 1, p. 89-101, 2014.

LEONCINI, M. P.; SILVA, M. T. Entendendo o futebol como um negócio: um estudo exploratório. Gestão \& Produção (UFSCAR. Impresso), v. 12, p. 11-23, 2005.

MARQUES, D. S. P.; COSTA, A. L. Governança em clubes de futebol: um estudo comparativo de três agremiações no estado de São Paulo. RAUSP, v. 44, n. 2, p. 118-130, 2009.

MAYER, M. M. Futebol: o negócio por trás do jogo - Estudo de Caso do São Paulo Futebol Clube. 2010. 78 f. Dissertação (Mestrado Executivo em Gestão Empresarial) - Fundação Getúlio Vargas, Rio de Janeiro, 2010.

MELLACI, M.; PETROKAS, L. A.; FAMÁ, R. Analysis of the impact of sports sponsorship by Banco Panamericano: an event study. Brazilian Business Review, v. 9, n. 3, p. 102-119, 2012.

NASCIMENTO, J. C. H. B.; NOSSA, V.; BERNARDES, J. R.; SOUSA, W. D. A eficiência dos maiores clubes de futebol brasileiros: evidências de uma análise longitudinal no período de 2006 a 2011. Revista Contabilidade Vista \& Revista, v. 26, n. 2, p. 137-161, 2015.

NEVES JÚNIOR, I. J.; MOREIRA, S. A.; SOUZA, A. S.; SILVEIRA, L. J. F. Fronteira de eficiência dos clubes de futebol do campeonato brasileiro série "A" de 2012. Revista Pensamento Contemporâneo em Administração, v. 9, n. 3, p. 121-137, 2015.

OLIVER, R. L. Whence Consumer Loyalty? Journal of Marketing, v. 63, n. 4, p. 33-44, 1999.

PERRUCI, F. F. Clube-empresa: o modelo brasileiro para transformação dos clubes de futebol em sociedades empresárias. 2006. 287 f. Dissertação (Mestrado em Direito) - Curso de Mestrado da Faculdade de Direito Milton Campos, Faculdade de Direito Milton Campos, Nova Lima, 2006.

RATTEN, V. Sport-based entrepreneurship: towards a new theory of entrepreneurship and sport management. International Entrepreneurship and Management Journal, v. 7, n. 1, p.57-69, 2011.

RATTEN, V. The dynamics of sport marketing Suggestions for marketing intelligence and planning. Marketing Intelligence \& Planning, v. 34, n. 2, p. 162-168, 2016. 
RATTEN, V.; RATTEN, H. International sport marketing: practical and future research implications. Journal of Business \& Industrial Marketing, v. 26, n. 8, p. 614-620, 2011.

REZENDE, A. J.; CUSTÓDIO. Uma análise da evidenciação dos direitos federativos nas demonstrações contábeis nos clubes de futebol brasileiros. Revista de Educação e Pesquisa em Contabilidade, v. 6, n. 3, p. 229-245, 2012.

REZENDE, A. J.; DALMÁCIO, F. Z.; SALGADO, A. L. Nível de disclosure das atividades operacionais, econômicas e financeiras dos clubes brasileiros. Revista Contabilidade, Gestão e Governança, Brasília, v. 13, n. 2, p. 36-50, 2010.

REZENDE, A. J.; DALMÁCIO, F. Z. Práticas de governança corporativa e indicadores de performance dos clubes de futebol: uma análise das relações estruturais. Contabilidade, Gestão e Governança, v. 18, n. 3, p. 105-125, 2015.

RIBEIRO, A. S.; LIMA, F. Portuguese football league efficiency and players' wages. Applied Economics Letters, v. 19, n. 6, p. 599-602, 2012.

ROBERTSON, R.; GIULIANOTTI, R. Fútbol, globalización y glocalización. Revista Internacional de Sociología - RIS, v. 64, n. 45, p. 9-35, 2006.

SENRA, L. F. A. C.; NANCI, L. C.; MELLO, J. C. C. B. S.; MEZA, L. A. Estudo sobre métodos de seleção de variáveis em DEA. Pesquisa Operacional, v. 27, n. 2, p. 191-207, 2007.

SILVA, J. A. F.; CARVALHO, F. A. A. Evidenciação e desempenho em organizações desportivas: um estudo empírico sobre clubes de futebol. Revista de Contabilidade e Organizações, v. 3, n. 6, p. 96-116, 2009.

SILVA, R. G. S.; AÑAÑA, E. S.; ALVES, C. E. D. S.; BORGES, G. R. Um estudo das relações entre a paixão dos torcedores e as marcas patrocinadoras de clubes de futebol. Revista Eletrônica de Estratégia \& Negócios, v. 7, n. 3, p. 63-90, 2014.

MELLO, J. C. C. B S.; MEZA, L.; GOMES, E. G.; SERAPIÃO, B. P.; LINS, M. P. E. Análise Envoltória de Dados no estudo da eficiência e dos benchmarks para companhias aéreas brasileiras. Pesquisa Operacional, v. 23, n. 2, p. 325-345, 2003.

SOLEIMANI-DAMANEH, J.; HAMIDI, M.; SAJADI, N. Evaluating the performance of iranian football teams utilizing linear programming. American Journal of Operations Research, v. 1, n. 2, p. 65-72, 2011.

SOMOGGI, A. Análise Prévia: Finanças dos maiores clubes brasileiros em 2012. Disponível em: $<$ http://www.ibdd.com.br/arquivos/Financas\%20Clubes\%20Brasileiros\%20-\%20Amir\%20 Somoggi\%20-Maio\%202013.pdf>. Acesso em: 17 junho 2016.

SUEYOSHI, T.; GOTO, M.; OMI, Y. Corporate governance and firm performance: Evidence from Japanese manufacturing industries after the lost decade. European Journal of Operational Research, v. 203, n. 3, p. 724-736, 2010.

SWEENEY, J. Sportscast: Ten controversial issues confronting the sports industry. The Futurist, v. 41, n. 1, p. 35-39, 2007.

TOBIN, J. Estimation of relationships for limited dependent variables. Econometria, v. 26, n. 1, p. 24-36, 1958.

WEBER, M. Economia e Sociedade. 1. ed. Tradução de Regis Barbosa e Karen Elsabe Barbosa. Brasília, DF: Editora Universidade de Brasília, 2004. 580 p. 
WOOLDRIGE, J. M. Introdução à econometria: uma abordagem moderna. São Paulo: Cengage Learning, p. 242, 2008.

ZUNINO, R. Comportamento de Compra de Torcedores de Clubes de Futebol: Um Estudo da Aquisição de Produtos dos Patrocinadores. In: ENCONTRO DE MARKETING DA ANPAD, 2., 2006, Rio de Janeiro. Anais... Rio de Janeiro: EMA, 2006. 